\title{
PENENTUAN JURUSAN PADA PROSES PENERIMAAN MAHASISWA DENGAN PENDEKATAN LOGIKA FUZZY
}

\author{
Umi Hayati \\ Program Studi Teknik Informatika STMIK IKMI Cirebon \\ Jl. Perjuangan No. 10 B, Majasem Cirebon \\ umi.haya41@gmail.com
}

\begin{abstract}
Abstrak
Memilih jurusan bukanlah urusan yang mudah. Banyak faktor yang harus diperhitungkan dan dipikirkan secara matang jangan sampai dalam memilih jurusan menyebabkan kerugian yang besar. Banyak cara untuk menentukan pemilihan jurusan, salah satunya adalah dengan menggunakan logika fuzzy. Penentuan jurusan ditentukan dari hasil tes seleksi bidang akademik dengan mata uji Matematika, Bahasa Inggris dan Pengetahuan Komputer. Dengan tujuan untuk merekomendasikan pemilihan jurusan yang tepat sesuai dengan kemampuan akademik dan meningkatkan kualitas. Dengan menggunakan Metode fuzzy inference model Mamdani metode max-min. Dicoba simulasi sistem dengan menggunakan perangkat lunak MATLAB Fuzzy Toolbox. Perancangan sistem dilakukan dalam beberapa tahap yaitu: (1) pembentukan himpunan fuzzy, (2) pembentukan aturan-aturan, (3) penentuan komposisi aturan, dan (4) penegasan (defuzzyfikasi). Defuzzyfikasi dilakukan dengan menggunakan metode Composite Moment, dengan tipe fungsi keanggotaan yang dipakai adalah mf-triangular, mftrapezoid dan mf-gaussian. Dari hasil pengujian yang dilakukan, menunjukkan bahwa tipe fungsi keanggotaan $m f$-triangular dan $m f$-trapezoid rata-rata menghasilkan tingkat akurasi yang hampir sama. Sedangkan tipe fungsi keanggotaan mf-gaussian menghasilkan tingkat akurasi tinggi untuk matematika sebesar 87,50\%, bahasa inggris $100 \%$ dan pengetahuan komputer $81,58 \%$.
\end{abstract}

Kata kunci :

Composite Moment, Logika Fuzzy, Model Mamdani, Seleksi Jurusan

\begin{abstract}
Choosing a major is not an easy matter. There are many factors that must be taken into account and carefully thought out so that in choosing a major, it will cause big losses. There are many ways to determine the selection of majors, one of which is by using fuzzy logic. Determination of majors is determined from the results of the selection test in the academic field with the subjects of Mathematics, English and Computer Knowledge. With the aim of recommending the selection of the right major according to academic abilities and improving quality. By using the fuzzy inference model Mamdani max-min method. The system simulation was tried using the MATLAB Fuzzy Toolbox software. The system design is carried out in several stages, namely: (1) formation of fuzzy sets, (2) formation of rules, (3) determination of the composition of rules, and (4) confirmation (defuzzification). Defuzzification is carried out using the Composite Moment method, with the types of membership functions used are mftriangular, mf-trapezoid and mf-gaussian. From the results of the tests carried out, it shows that the mftriangular and mf-trapezoid membership function types produce almost the same level of accuracy. While the membership function type mf-gaussian produces a high level of accuracy for mathematics by $87.50 \%$, English $100 \%$ and computer knowledge $81.58 \%$.
\end{abstract}

Keywords :

Composite Moment, Fuzzy Logic, Mamdani Model, Major Selection. 


\section{Pendahuluan}

Sebuah lembaga pendidikan membutuhkan suatu bentuk sistem pendukung pengambilan keputusan dalam menentukan jurusan yang sesuai bagi mahasiswanya. Keputusan yang diambil oleh mahasiswa dalam memilih jurusan, mungkin hampir tepat sesuai dengan kemampuan akademik dan minat siswa atau ada kemungkinan pengambilan keputusan pemilihan jurusan tersebut, tidak tepat. Oleh karena itu pembuat keputusan pemilihan jurusan harus benarbenar mempertimbangkan pilihan yang tepat dan akurat, sesuai dengan kemampuan dasar jurusan yang dipilih oleh mahasiswa. Penentuan jurusan mahasiswa berpengaruh terhadap kegiatan akademik mahasiswa. Dengan bantuan pemilihan jurusan, diharapkan setiap mahasiswa dapat lebih fokus karena telah sesuai dengan kemampuan dasar dalam bidangnya, minat dan juga bakatnya. Peneliti mencoba melakukan kajian dengan mengambil permasalahan penentuan jurusan pada proses penerimaan mahasiswa, dengan harapan untuk mencoba memberikan solusi dalam pemilihan jurusan yang tepat dan memperkecil jumlah mahasiswa yang tidak melanjutkan studinya.

Pada kasus ini peneliti memilih penyelesaian menggunakan pendekatan metode logika Fuzzy, dengan pertimbangan bahwa metode ini mampu diterapkan pada masalah-masalah yang tidak linier, uncertain, variabel yang komplek dan tingkat pendekatan yang relatif intuitif dapat diterima dengan pemikiran manusia. Heni Hapsari [2], memberikan informasi mengenai universitas yang mempunyai banyak jurusan, memberikan bantuan rekomendasi kepada calon mahasiswanya dalam pemilihan jurusan, dengan proses pengolahan data melalui perhitungan inferensi logika fuzzy. Sedangkan oleh Bahar [3] menerapkan algoritma Fuzzy C-Means dalam penentuan pemilihan dengan 81 sampel data uji siswa, dengan tingkat akurasi yang lebih tinggi (rata-rata 78,39\%), Penelitian Samuel Lukas [4] dengan Logika Fuzzy dapat digunakan untuk membantu proses pemilihan minat mahasiswa pada jurusan yang dipilihnya.

Dengan pertimbangan metode, hasil dan solusi dari beberapa peneliti sebelumnya, maka peneliti mencoba melakukan penelitian ini dengan menggunakan pendekatan Inferensi Logika Fuzzy yang dapat digunakan untuk memperbaiki pemilihan jurusan dengan mengklasifikasikan pola penjurusan yang dipilih oleh mahasiswa, dengan mempertimbangkan nilai hasil tes kemampuan akademik.

Pada penelitian ini dilakukan dengan batasan, parameter dan indek yang berbeda dari penelitian sebelumnya, dengan menurunkan beberapa kriteria yang disusun dalam beberapa kategori diantaranya: (i) Kriteria masukan adalah Nilai Matematika, Nilai Bahasa Inggris dan Nilai Pengetahuan Komputer, yang masing-masing dikelompokkan dalam 3 (tiga) himpunan fungsi keanggotaan. (ii) Kriteria keluaran adalah nilai indeks dari program studi: Teknik Informatika (S1), Sistem Informasi (S1), Teknik Informatika (D3), Teknik Komputer (D3) dan Manajemen Informatika (D3)

Sistematika Penulisan diorganisasikan ke dalam bagian-bagian sebagai berikut: Bagian 1 akan dijelaskan mengenai Pendahuluan yang melandasi penelitian ini. Bagian 2 menjelaskan tentang penelitian-penelitian terkait khususnya mengenani penjurusan dan landasan teori untuk teori-teori yang digunakan serta kerangka pemikiran. Bagian 3 membahas metode penelitian yang digunakan, secara umum terdiri dari teknik pengumpulan data yang digunakan, proses pengolahan awal data, metode yang diusulkan, pengujian metode, serta evaluasi dan hasil. Bagian 4 berisi Hasil dan pembahasan dari hasil penelitian yang dilakukan. Bagian ini akan berisi data-data dan hasil analisa tingkat akurasi dari metode yang diusulkan. Bagian 5 menyajikan sebuah ringkasan dari hasil penelitian.

\section{KAJIAN LITERATUR}

Penelitian yang dilakukan oleh Heni Hapsari menggunakan metoda Fuzzy Inference SystemMamdani, dengan memasukkan paremeter penilaian bakat siswa mampu menunjukan perbedaan yang signifikan tentang informasi pemilihan institusi yang mempunyai banyak jurusan. Jurusan yang diperoleh telah melalui perhitungan logika fuzzy dengan datadata yang valid. [2]

Penelitian oleh Bahar, menggunakan metoda Fuzzy C-Means dalam penentuan jurusan di Sekolah Menengah Atas pada 81 sampel data siswa yang diuji dalam penelitian ini menunjukkan bahwa Algoritma Fuzzy C-Means memiliki tingkat akurasi yang lebih tinggi (rata-rata78,39\%), jika dibandingkan dengan metode penentuan jurusan secara manual yang biasa

Umi Hayati 
dilakukan, hanya memiliki tingkat akurasi rata-rata 56,17\%). [3]

Penelitian dengan metoda logika fuzzy yang dilakukan oleh Samuel Lukas mendapatkan aturan hubungan antara parameter matakuliah dan nilai kompetensi, parameter nilai kompetensi dan nilai peminatan memiliki peranan yang besar terhadap hasil akhir dimana nilai yang dihasilkan sebagai nilai peminatan tidak berbeda jauh, kecuali jika input nilai yang dimasukkan lebih besar. [4]

M. Gesung Gautama dengan metoda Fuzzy Inference System-Mamdani mengevaluasi Output jurusan IPA dan IPS untuk kedua FIS tidak berbeda secara signifikan dan memberikan keputusan yang sama. [5]

Penelitian yang dilakukan oleh Hafsah Heru Cahyadengan Logika Fuzzy, menghasilkan nilai keanggotaan memenuhi target pemilihan dan output data disertai nilai dukungan prosentase kedekatan atau nilai keanggotaan. [6]

Mutia Sidratul dengan metoda Logika Fuzzy mendapatkan hasil penelitian bahwa Sistem pendukung keputusan dapat meminimalisir kesalahan dan penentuan status dan penjurusan. [7]

Perancangan yang mengintegrasikan Fuzzy dengan AHP degan MF-trianggular yang diimplementasikan pada DSS adalah hasil dari penelitian yang didapatkan oleh Defi Rahmah Fatih dengan menggunakan metoda Logika Fuzzy Analisis Hirarki Proses. [8]

Metoda Mamdani sering juga dikenal dengan nama metoda Max-Min. [9] Dengan menggunakan Metode fuzzy inference model Mamdani metode maxmin. Dicoba simulasi sistem dengan menggunakan perangkat lunak MATLAB Fuzzy Toolbox. Perancangan sistem dilakukan dalam beberapa tahap yaitu: a. pembentukan himpunan fuzzy, b. pembentukan aturan-aturan, c. penentuan komposisi aturan, dan d. penegasan (defuzzyfikasi). [10].

Dengan metoda Fuzzy yang diusulkan maka: (i) Pembentukan himpunan fuzzy, untuk masingmasing variabel masukan, ditentukan suatu fungsi fuzzifikasi yang sesuai. Pada metode Mamdani, variabel masukan maupun variabel keluaran dibagi menjadi beberapa himpunan fuzzy. (ii) Aplikasi fungsi implikasi, dengan menyusun basis aturan, yaitu aturan-aturan berupa implikasi-implikasi fuzzy yang menyatakan relasi antara variabel masukan dengan variabel keluaran, dengan fungsi implikasi minimun sebagai berikut: Jika a adalah $\mathrm{A} i$ dan $b$ adalah $\mathrm{B} i$, maka $c$ adalah $\mathrm{C} i$ dengan $\mathrm{A} i, \mathrm{~B} i$, dan $\mathrm{C} i$ adalah predikat-predikat fuzzy yang merupakan nilai linguistik dari masing-masing variabel.

Banyaknya aturan ditentukan oleh banyaknya nilai linguistik untuk masing-masing variabel masukan. (iii) Komposisi aturan inferensi diperoleh dari kumpulan dan kolerasi antar aturan yang digunakan dalam melakukan inferensi sistem fuzzy, yaitu: Metode Max (Maximum). Secara umum dapat dituliskan:

$\mu(x i)=\max (\mu s f(x i), \mu k f(x i))$

dengan: ke- $i$

$\mu \mathrm{sf}(x i)=$ nilai $M F$ solusi fuzzy sampai aturan

$\mu \mathrm{kf}(x i)=$ nilai $M F$ konsekuen fuzzy aturan ke- $i$

Dengan metode additive, yakni dengan cara melakukan penjumlahan terhadap semua keluaran daerah fuzzy, probabilistik $O R$, melakukan perkalian terhadap semua keluaran daerah fuzzy, agregasi antar himpunan-himpunan fuzzy digunakan agregasi maksimum dan defuzzifikasi centroid.

Langkah langkah yang dilakukan dalam penelitian ini adalah Pengumpulan data.Pemilihan fungsi keanggotaan, Perancangan sistem inferensi fuzzy, Pembentukan himpunan fuzzy, Pembentukan aturan fuzzy, Pemodelan dengan perangkat lunak (FuzzyToolBox), Eksekusi model, Hasil eksekusi, normalisasi, lookup tabel dan komparasi.

Langkah-langkah tersebut dapat dilihat pada gambar diagram alur metode penelitian sebagai berikut: 


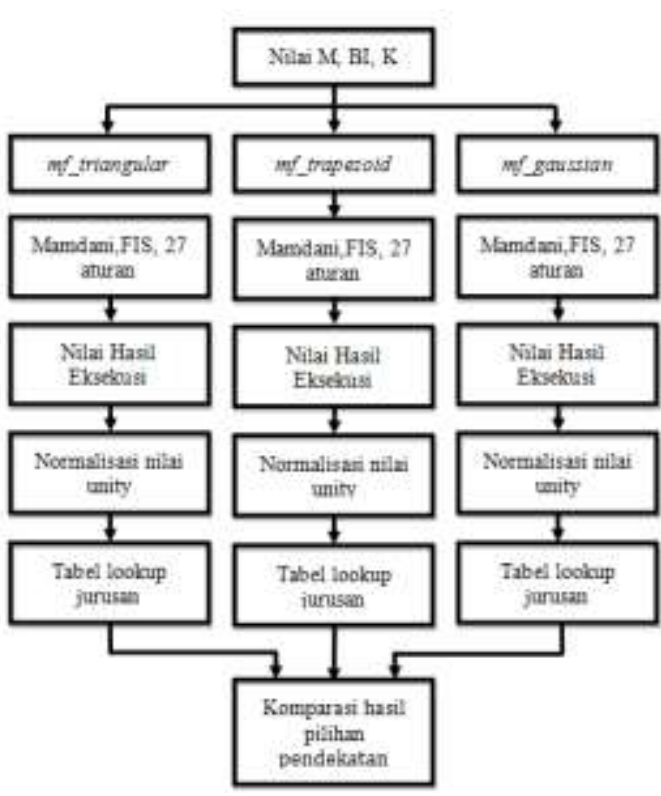

Gambar 1. Diagram alur metode penelitian

\section{Analisis dan Perancangan}

Data yang digunakan dalam pengujian adalah berupa data hasil tes seleksi mata uji Matematika, Bahasa Inggris dan Pengetahuan Komputer yang diperoleh dari database akademik bagian Penerimaan Mahasiswa Baru tahun 2016/2017. [1]

Pengujian menggunakan operator pengubah linguistik yaitu tinggi, randah dan sedang. Variabel linguistik dapat dinyatakan sebagai pasangan $(u, T(u), X)$, dengan $u$ menunjukkan nama variabel. Selanjutnya $T(u)$ disingkat menjadi $T$ dan disebut term-set. maka perangkat term-set $T(u)$ ditulis sebagai berikut:

$\mathrm{T}($ Nilai matematika $)=\{\mathrm{M} 1, \mathrm{M} 2, \mathrm{M} 3\}=\{$ rendah, sedang, tinggi\}

$$
\begin{aligned}
\text { M1 } & =\text { rendah: } \mu(x)=\exp \left(-\frac{(x-10)^{2}}{20}\right) \\
\text { M2 } & =\text { sedang }: \mu(x)=\exp \left(-\frac{(x-15)^{2}}{20}\right) \\
\text { M3 } & =\text { tinggi }
\end{aligned}
$$

$\mathrm{T}($ Nilai Bhs Inggris $)=\{\mathrm{B} 1, \mathrm{~B} 2, \mathrm{~B} 3\}=\{$ rendah, sedang, tinggi\}

$$
\mathrm{B} 1=\text { rendah }: \mu(x)=\exp \left(-\frac{(x-10)^{2}}{20}\right)
$$

$$
\begin{gathered}
\mathrm{B} 2=\text { sedang } \\
\mu(x)=\exp \left(-\frac{(x-15)^{2}}{20}\right) \\
\mathrm{B} 2=\text { tinggi }: \quad \mu(x)=\exp \left(-\frac{(x-20)^{2}}{20}\right.
\end{gathered}
$$

$\mathrm{T}($ Nilai Komputer $)=\{\mathrm{K} 1, \mathrm{~K} 2, \mathrm{~K} 3\}=\{$ rendah, sedang, tinggi\}

$$
\begin{aligned}
\mathrm{K} 1 & =\operatorname{rendah}: \mu(x)=\exp \left(-\frac{(x-10)^{2}}{20}\right) \\
\mathrm{K} 2 & =\operatorname{sedang} \\
\mu(x)= & \exp \left(-\frac{(x-15)^{2}}{20}\right) \\
\mathrm{K} 2 & =\operatorname{tinggi} \\
\mu(x) & =\exp \left(-\frac{(x-20)^{2}}{20}\right)
\end{aligned}
$$

Sistem Inferensi Fuzzy penentuan jurusan yang dibuat mempunyai tiga variabel input. Variabel input terdiri atas nilai Matematika, Bahasa Inggris dan Pengetahuan Komputer. Untuk penelitian ini variable masukan nilai bakat dan minat diabaikan.

Variabel masukan nilai akademis hasil test ujian masuk untuk subyek Matematika, Bahasa Inggris dan Pengetahuan Komputer mempunyai rentang nilai 0 sampai dengan 20. Relasi antar variabel masukan dengan keluaran diatur dengan kombinasi aturan.

Himpunan fuzzy yang dibuat untuk tiap-tiap variabel masukan terlihat pada Fungsi derajat keanggotaan yang digunakan pada tiap variabel fuzzy ditentukan berdasarkan pada hasil penggalian data keadaan di Institusi yang dijadikan tempat penelitian.

Ada 27 aturan kombinasi nilai Matematik, Bahasa Inggris dan Pengetahuan Komputer, dengan ketentuan bahwa setiap aturan yang dibentuk menyertakan semua variabel.

Analisis dilakukan dengan mencari tingkat korelasi keluaran terhadap nilai parameter masukan, untuk mengetahui sejauhmana hasil rekomendasi yang bisa terukur dari pemilihan jurusan oleh mahasiswa yang bersangkutan. Pada penelitian ini menggunakan nilai sample 238 mahasiswa. Perhitungan rekomendasi tersebut dikelompokkan dalam kriteria kategori yang sudah ditentukan.

Hasil pengujian dapat dilihat sebagai berikut:
Umi Hayati

Jurnal Ilmiah Teknologi Informasi Terapan

Volume 8, No 1, 15 Desember 2021 


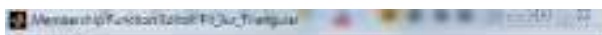

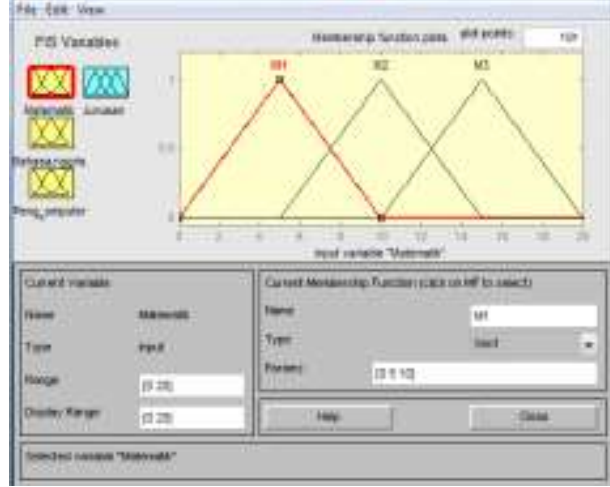

Gambar 2. Triangular_MF FIS Variabel Masukan 1,2 dan 3

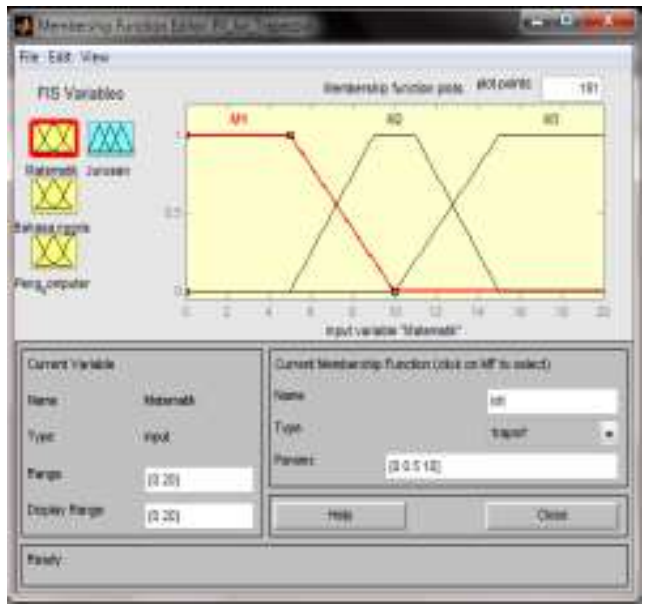

Gambar 3. Trapezoid_MF FIS Variabel Masukan 1,2 dan 3

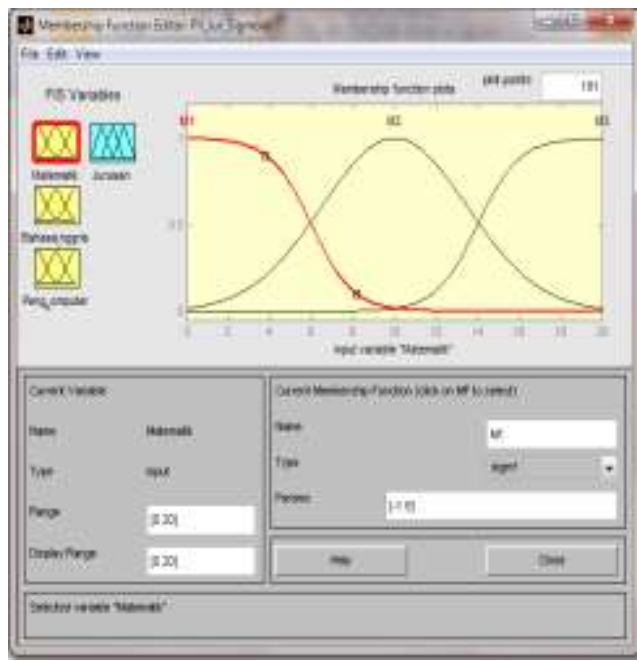

Gambar 4. Signoid_ MF FIS Variabel Masukan 1,2 dan 3

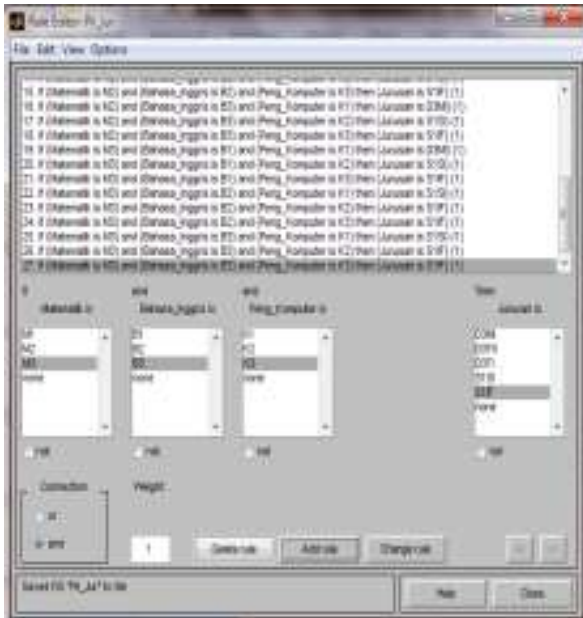

Gambar 5. Aturan relasi masukan dengan keluaran

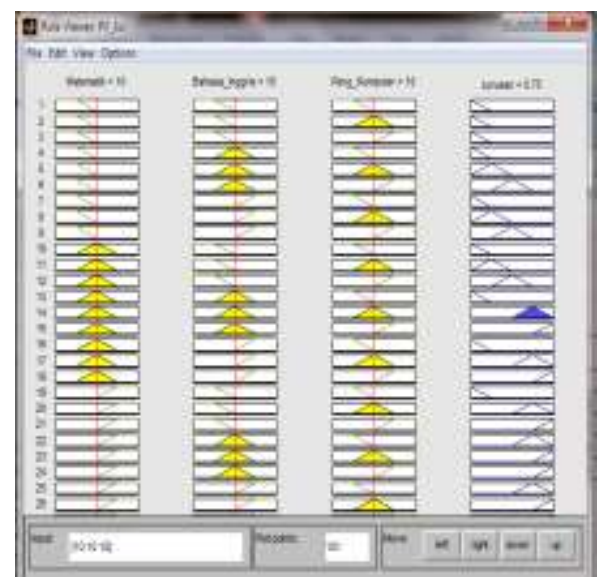

Gambar 6. Rule viewer FIS

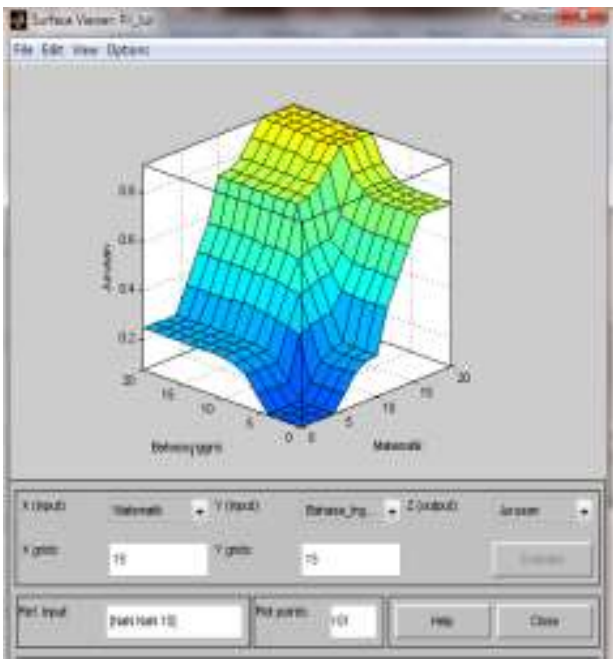

Gambar 7. Plot permukaan relasi aturan 


\section{Pengujian MF-Triangular nilai matematika sedang.}

Dari hasil pengujian matematik didapatkan 156 orang yang memiliki nilai matematika sedang dan setelah melalui perhitungan berdasarkan nilai kriteria jurusan maka didapat 56 orang yang sesuai dengan pilihan program studi. Hasil presentasi ketepatan pemilihan adalah $35,90 \%$

- Tabulasi hasil pengujian MF-Triangular nilai matematika sedang

\begin{tabular}{|c|c|c|c|c|c|c|c|}
\hline No & $\begin{array}{c}\text { Nmat } \\
\text { TG }\end{array}$ & $\begin{array}{c}\text { NBIng } \\
\text { TG }\end{array}$ & $\begin{array}{c}\text { Nkom } \\
\text { TG }\end{array}$ & $\begin{array}{c}\text { Hasil } \\
\text { TG }\end{array}$ & Nyata & Norm & Tool \\
\hline 75 & 7 & 2 & 1 & D3-MI & S1-IF & 4,51 & 0,0902 \\
\hline 76 & 7 & 2 & 5 & D3-MI & S1-IF & 4,51 & 0,0902 \\
\hline 77 & 7 & 2 & 7 & D3-TI & S1-IF & 10,16 & 0,2031 \\
\hline 78 & 7 & 2 & 10 & D3-TI & $\begin{array}{l}\text { D3- } \\
\text { TK }\end{array}$ & 10,16 & 0,2031 \\
\hline 79 & 7 & 2 & 14 & S1-sl & D3-TI & 16,59 & 0,3318 \\
\hline 80 & 7 & 3 & 1 & D3-MI & $\begin{array}{l}\text { D3- } \\
\text { MII }\end{array}$ & 4,51 & 0,0902 \\
\hline 81 & 7 & 3 & 1 & D3-MI & S1-IF & 4,51 & 0,0902 \\
\hline 82 & 7 & 3 & 7 & D3.TI & D3-TI & 10,16 & 0,2031 \\
\hline 83 & 7 & 3 & 11 & D3-TI & S1-IF & 14,00 & 0,2800 \\
\hline 84 & 7 & 3 & 13 & S1-SI & D3-TI & 16,19 & 0,3238 \\
\hline 85 & 7 & 3 & 16 & S1-SI & S1-IF & 16,75 & 0,3349 \\
\hline 86 & 7 & 4 & 7 & D3-ח & S1-IF & 10,16 & 0,2031 \\
\hline$\ldots$ & $\ldots$ & $\ldots$ & $\ldots$ & $\ldots$ & $\ldots$ & $\ldots$ & $\ldots$ \\
\hline+ & $\ldots$ & + & - & $\ldots$ & + & + & $\ldots$ \\
\hline 229 & 13 & 5 & 16 & S1-IF & S1-IF & 33,26 & 0,6651 \\
\hline \multirow[t]{3}{*}{230} & 13 & 8 & 13 & S1-IF & S1-IF & 27,67 & 0,5533 \\
\hline & & & s & 56 & 156 & & \\
\hline & & & & $35,90 \%$ & & & \\
\hline
\end{tabular}

\section{Pengujian MF-Triangular nilai matematika tinggi.}

Dari hasil pengujian matematik didapatkan 8 orang yang memiliki nilai matematika tinggi dan setelah melalui perhitungan berdasarkan nilai kriteria jurusan maka didapat 5 orang yang sesuai dengan pilihan program studi. Hasil presentasi ketepatan pemilihan adalah $62,50 \%$

- Tabulasi hasil pengujian MF-Triangular nilai matematika Tinggi

\begin{tabular}{|c|c|c|c|c|c|c|c|}
\hline No & $\begin{array}{c}\text { Nmat } \\
\text { TG }\end{array}$ & $\begin{array}{c}\text { NBIng } \\
\text { TG }\end{array}$ & $\begin{array}{c}\text { Nkom } \\
\text { TG }\end{array}$ & $\begin{array}{c}\text { Hasil } \\
\text { TG }\end{array}$ & Nyata & Norm & Tool \\
\hline 231 & 14 & 2 & 6 & S1-SI & S1-IF & 18,06 & 0,3611 \\
\hline 232 & 14 & 2 & 7 & S1-IF & S1-IF & 23,15 & 0,4630 \\
\hline 233 & 14 & 3 & 8 & S1-IF & S1-IF & 26,78 & 0,5356 \\
\hline 234 & 14 & 3 & 16 & S1-IF & D3-MI & 37,08 & 0,7415 \\
\hline 235 & 14 & 5 & 6 & S1-SI & S1-IF & 18,06 & 0,3611 \\
\hline 236 & 14 & 7 & 8 & S1-IF & S1-IF & 28,09 & 0,5618 \\
\hline 237 & 15 & 7 & 10 & S1-IF & S1-IF & 38,55 & 0,7709 \\
\hline 238 & 16 & 4 & 8 & S1-IF & S1-IF & 28,37 & 0,5673 \\
\hline & & & T & $\mathbf{5}$ & $\mathbf{8}$ & & \\
\hline & & & & $\mathbf{6 2 , 5 0 \%}$ & & & \\
\hline
\end{tabular}

\section{Pengujian MF-Trapezoid nilai matematika sedang.}

Dari hasil pengujian matematik didapatkan 156 orang yang memiliki nilai matematika sedang dan setelah melalui perhitungan berdasarkan nilai kriteria jurusan maka didapat 58 orang yang sesuai dengan pilihan program studi. Hasil presentasi ketepatan pemilihan adalah $37,18 \%$

- Tabulasi hasil pengujian MF-Trapezoid nilai matematika Sedang

\begin{tabular}{|c|c|c|c|c|c|c|c|}
\hline No & $\begin{array}{c}\text { Nmat } \\
\text { TZ }\end{array}$ & $\begin{array}{c}\text { NBIng } \\
\text { TZ }\end{array}$ & $\begin{array}{c}\text { Nkom } \\
\text { TZ }\end{array}$ & $\begin{array}{c}\text { Hasil } \\
\text { TZ }\end{array}$ & Nyata & Norm & Tool \\
\hline 75 & 7 & 2 & 1 & D3-MI & S1-IF & 4,51 & 0,0902 \\
\hline 76 & 7 & 2 & 5 & D3-MI & S1-IF & 4,51 & 0,0902 \\
\hline 77 & 7 & 2 & 7 & D3-TI & S1-IF & 10,47 & 0,2094 \\
\hline 78 & 7 & 2 & 10 & D3-TI & D3-TK & 10,47 & 0,2094 \\
\hline 79 & 7 & 2 & 14 & S1-SI & D3-TI & 17,26 & 0,3451 \\
\hline 80 & 7 & 3 & 1 & D3-MI & D3-MI & 4,51 & 0,0902 \\
\hline 81 & 7 & 3 & 1 & D3-MI & S1-IF & 4,51 & 0,0902 \\
\hline 82 & 7 & 3 & 7 & D3-TI & D3-TI & 10,47 & 0,2094 \\
\hline 83 & 7 & 3 & 11 & D3-TI & S1-IF & 13,92 & 0,2784 \\
\hline 84 & 7 & 3 & 13 & S1-SI & D3-TI & 16,64 & 0,3327 \\
\hline 85 & 7 & 3 & 16 & S1-SI & S1-IF & 17,51 & 0,3502 \\
\hline 86 & 7 & 4 & 7 & D3-TI & S1-IF & 10,47 & 0,2094 \\
\hline$\ldots$ & $\ldots$ & $\ldots$ & $\ldots$ & $\ldots$ & $\ldots$ & $\ldots$ & $\ldots$ \\
\hline$\ldots$ & $\ldots$ & $\ldots$ & $\ldots$ & $\ldots$ & $\ldots$ & $\ldots$ & $\ldots$ \\
\hline 229 & 13 & 5 & 16 & S1-IF & S1-IF & 32,49 & 0,6498 \\
\hline 230 & 13 & 8 & 13 & S1-IF & S1-IF & 28,30 & 0,5533 \\
\hline & & & S & $\mathbf{5 8}$ & $\mathbf{1 5 6}$ & & \\
\hline & & & & $\mathbf{3 7 , 1 8} \%$ & & & \\
\hline
\end{tabular}

Umi Hayati

Jurnal Ilmiah Teknologi Informasi Terapan

Volume 8, No 1, 15 Desember 2021 


\section{Pengujian MF-Trapezoid nilai matematika tinggi.}

Dari hasil pengujian matematik didapatkan 8 orang yang memiliki nilai matematika tinggi dan setelah melalui perhitungan berdasarkan nilai kriteria jurusan maka didapat 5 orang yang sesuai dengan pilihan program studi. Hasil presentasi ketepatan pemilihan adalah $62,50 \%$

- Tabulasi hasil pengujian MF-Trapezoid nilai matematika Tinggi

\begin{tabular}{|c|c|c|c|c|c|c|c|}
\hline No & $\begin{array}{c}\text { Nmat } \\
\text { TZ }\end{array}$ & $\begin{array}{c}\text { NBIng } \\
\text { TZ }\end{array}$ & $\begin{array}{c}\text { Nkom } \\
\text { TZ }\end{array}$ & $\begin{array}{c}\text { Hasil } \\
\text { TZ }\end{array}$ & Nyata & Norm & Tool \\
\hline 231 & 14 & 2 & 6 & S1-SI & S1-IF & 19,23 & 0,3846 \\
\hline 232 & 14 & 2 & 7 & S1-IF & S1-IF & 24,00 & 0,4799 \\
\hline 233 & 14 & 3 & 8 & S1-IF & S1-IF & 27,11 & 0,5421 \\
\hline 234 & 14 & 3 & 16 & S1-IF & D3-MI & 36,08 & 0,7215 \\
\hline 235 & 14 & 5 & 6 & S1-SI & S1-IF & 19,23 & 0,3846 \\
\hline 236 & 14 & 7 & 8 & S1-IF & S1-IF & 28,28 & 0,5656 \\
\hline 236 & 5 & 7 & 10 & S1-IF & S1-IF & 38,97 & 0,7793 \\
\hline 238 & 16 & 4 & 8 & S1-IF & S1-IF & 29,07 & 0,5814 \\
\hline & & & $\mathbf{T}$ & $\mathbf{5}$ & $\mathbf{8}$ & & \\
\hline & & & & $\mathbf{6 2 , 5 0} \%$ & & & \\
\hline
\end{tabular}

\section{Pengujian MF-Gaussian nilai matematika sedang.}

Dari hasil pengujian matematik didapatkan 156 orang yang memiliki nilai matematika sedang dan setelah melalui perhitungan berdasarkan nilai kriteria jurusan maka didapat 82 orang yang sesuai dengan pilihan program studi. Hasil presentasi ketepatan pemilihan adalah 52,56\%

- Tabulasi hasil pengujian MF-Gaussian nilai matematika Sedang

\begin{tabular}{|c|c|c|c|c|c|c|c|}
\hline No & $\begin{array}{c}\text { Nmat } \\
\text { GS }\end{array}$ & $\begin{array}{c}\text { NBIng } \\
\text { GS }\end{array}$ & $\begin{array}{c}\text { Nkom } \\
\text { GS }\end{array}$ & $\begin{array}{c}\text { Hasil } \\
\text { GS }\end{array}$ & Nyata & Norm & Tool \\
\hline 75 & 7 & 2 & 1 & D3-TK & S1-IF & 9,51 & 0,1902 \\
\hline 76 & 7 & 2 & 5 & D3-TI & S1-IF & 13,81 & 0,2761 \\
\hline 77 & 7 & 2 & 7 & S1-SI & S1-IF & 15,45 & 0,3089 \\
\hline 78 & 7 & 2 & 10 & S1-SI & D3-TK & 15,45 & 0,3089 \\
\hline 79 & 7 & 2 & 14 & S1-SI & D3-TI & 19,48 & 0,3896 \\
\hline 80 & 7 & 3 & 1 & D3-TK & D3-MI & 9,51 & 0,1902 \\
\hline 81 & 7 & 3 & 1 & D3-TK & S1-IF & 9,51 & 0,1902 \\
\hline 82 & 7 & 3 & 7 & S1-SI & D3-TI & 17,50 & 0,3500 \\
\hline 83 & 7 & 3 & 11 & S1-SI & S1-IF & 17,50 & 0,3500 \\
\hline 84 & 7 & 3 & 13 & S1-SI & D3-TI & 18,81 & 0,3761 \\
\hline 85 & 7 & 3 & 16 & S1-IF & S1-IF & 23,03 & 0,4605 \\
\hline 86 & 7 & 4 & 7 & S1-SI & S1-IF & 19,70 & 0,3940 \\
\hline$\ldots$ & $\ldots$ & $\ldots$ & $\ldots$ & $\ldots$ & $\ldots$ & $\ldots$ & $\ldots$ \\
\hline$\ldots$ & $\ldots$ & $\ldots$ & $\ldots$ & $\ldots$ & $\ldots$ & $\ldots$ & $\ldots$ \\
\hline 229 & 13 & 5 & 16 & S1-IF & S1-IF & 26,74 & 0,5348 \\
\hline 230 & 13 & 8 & 13 & S1-IF & S1-IF & 32,92 & 0,6584 \\
\hline & & & S & $\mathbf{8 2}$ & $\mathbf{l 5 6}$ & & \\
\hline & & & & $\mathbf{5 2 , 5 6 \%}$ & & & \\
\hline
\end{tabular}

\section{Pengujian MF-Gaussian nilai matematika tinggi.}

Dari hasil pengujian matematik didapatkan 8 orang yang memiliki nilai matematika tinggi dan setelah melalui perhitungan berdasarkan nilai kriteria jurusan maka didapat 7 orang yang sesuai dengan pilihan program studi. Hasil presentasi ketepatan pemilihan adalah $87,50 \%$

- Tabulasi hasil pengujian MF-Gaussian nilai matematika tinggi

\begin{tabular}{|l|c|c|c|c|c|c|c|}
\hline No & $\begin{array}{c}\text { Nmat } \\
\text { GS }\end{array}$ & $\begin{array}{c}\text { NBIng } \\
\text { GS }\end{array}$ & $\begin{array}{c}\text { Nkom } \\
\text { GS }\end{array}$ & $\begin{array}{c}\text { Hasil } \\
\text { GS }\end{array}$ & Nyata & Norm & Tool \\
\hline 231 & 14 & 2 & 6 & S1-IF & S1-IF & 22,87 & 0,4574 \\
\hline 232 & 14 & 2 & 7 & S1-IF & S1-IF & 24,19 & 0,4838 \\
\hline 233 & 14 & 3 & 8 & S1-IF & S1-IF & 24,87 & 0,4974 \\
\hline 234 & 14 & 3 & 16 & S1-IF & D3-MI & 28,05 & 0,5609 \\
\hline 235 & 14 & 5 & 6 & S1-IF & S1-IF & 24,00 & 0,4799 \\
\hline 236 & 14 & 7 & 8 & S1-IF & S1-IF & 29,96 & 0,5991 \\
\hline 237 & 15 & 7 & 10 & S1-IF & S1-IF & 30,39 & 0,6077 \\
\hline 238 & 16 & 4 & 8 & S1-IF & S1-IF & 30,53 & 0,6105 \\
\hline & & & T & $\mathbf{7}$ & $\mathbf{8}$ & & \\
\hline & & & & $\mathbf{8 7 , 5 0 \%}$ & & & \\
\hline
\end{tabular}

Umi Hayati

Jurnal Ilmiah Teknologi Informasi Terapan

Volume 8, No 1, 15 Desember 2021 


\section{KESIMPULAN DAN SARAN}

Dari hasil pembahasan/penelitian, maka dapat disimpulkan sebagai berikut:

1. Hasil uji penelitian dengan fungsi keanggotaan variabel masukan yang berbeda (mf-triangular, mf-trapezoid dan mf-gaussian) dilakukan untuk dapat digunakan sebagai pembanding akan ketepatan hasil keluaran metode sistem. Untuk ketiga atribut dan pada semua tipe MF, didapatkan nilai ketepatan tertinggi pada kriteria tinggi. Ketepatan atribut Matematika tertinggi ada pada MF Gaussian kriteria tinggi yaitu sebesar 87,5\%. Nilai Bahasa Inggris memiliki tingkat ketepatan $100 \%$ pada semua MF dengan kriteria tinggi. Nilai Komputer memiliki ketepatan tertinggi pada MF Gaussian dengan kriteria tinggi yaitu sebesar $81,58 \%$.

2. Penerapan model logika fuzzy Mamdani dalam penentuan jurusan ini dapat memberikan rekomendasi alternatif untuk penentuan jurusan yang tepat dan terarah sesuai dengan kemampuan yang dimiliki oleh calon mahasiswa, dengan hasil ketepatan pilihan program studi yang dipilih.

3. Logika fuzzy dapat diterapkan dalam memilih salah satu jurusan di Perguruan Tinggi dengan kemungkinan hasil yang lebih baik, karena setiap keluaran data disertai atau diberikan nilai dukungan yaitu persentase kedekatan.

\section{REFERENSI}

, Data base Akademik Institusi X.

Heni Hapsari, Aplikasi Fuzzy Inference System Metode Mamdani Untuk Pemilihan Jurusan di Perguruan Tinggi, Tesis, UIN Sunan Kalijaga Yogyakarta, 2012.

Bahar, Penentuan Jurusan Sekolah Menengah Atas Dengan Algoritma Fuzzy C-Means, Tesis Pacasarjana Universitas Dian Nuswantoro, 2012.

Samuel Lukas, Penerapan Logika Fuzzy Dalam Pengambilan Keputusan Untuk Jalur Peminatan Mahasiswa, Konferensi Nasional Sistem dan Informatika 2009; Bali, November 14, 2009.
Mohammad Glesung Gautama, Penentuan Jurusan di SMAN 8 Surakarta Dengan Fuzzy Inference System Mamdani, Universitas Sebelas Maret. 2010.

Hafsah, Heru Cahya Rustamaji, Yulia Inayati, Sistem Pendukung Keputusan Pemilihan Jurusan di SMU Dengan Logika Fuzzy, Seminar Nasional Informatika 2008

Mutia Sidratull Muntaha, Penerapan Sistem Pengambilan Keputusan untuk menyeleksi calon siswa SMK berdasarkan hasil test menggunakan Metode Fuzzy, Universitas Komputer Indonesia Bandung, 2007.

Fatih, Delfi dkk.,DSS Untuk Rekomendasi Pemilihan Jurusan Pada Perguruan Tinggi bagi siswa SMU,SNATI, Yogyakarta, 2012.

Kusumadewi, Sri, dan Hari, Purnomo, Aplikasi Logika Fuzzy untuk Pendukung Keputusan, Graha Ilmu, Yogyakarta, 2010.

Kusumadewi, Sri, Analisis dan Desain Sistem Fuzzy menggunakan Tool Box Matlab, edisi pertama. Penerbit Graha Ilmu, Jakarta, 2002.

Susilo, F, Pengantar Himpunan dan Logika Kabur Serta Aplikasinya, Universitas Sanata Dharma, Yogyakarta, 2003. 